\title{
Inflammatory Reaction to Fabric Collars From Percutaneous Antennas Attached to Intracoelomic Radio Transmitters Implanted in Harlequin Ducks (Histrionicus histrionicus)
}

\author{
Daniel M. Mulcahy, PhD, DVM, Dipl ACZM, K. A. Burek, DVM, MS, Dipl ACVP, \\ and Daniel Esler, MS, PhD
}

\begin{abstract}
In wild birds implanted intracoelomically with radio transmitters, a synthetic fabric collar placed around the base of a percutaneous antenna is believed to function as a barrier to contamination of the coelom. We examined 13 fabric collars recovered from percutaneous antennas of radio transmitters implanted intracoelomically in harlequin ducks (Histrionicus histrionicus) 12 months earlier. Both the transmitters and antenna collars were encapsulated in fibrous connective tissue, with adhesions to internal organs. Histologically, bacteria were evident at the fabric-plastic interface in 8 of 10 collars examined in cross section and along the length of the collar in 3 collars examined longitudinally. Bacteria were confined within the fibrotic sheath surrounding the transmitter and the antenna collar in all birds. No evidence of chronic systemic effects secondary to implantation was present on hematologic or serum biochemical testing. These findings indicate that antenna collars do not prevent the entry of bacteria along the percutaneous antenna but may help stabilize the antenna and minimize coelomic contamination. We conclude that radio transmitters implanted into the coelom of harlequin ducks do not appear to cause significant health problems for at least 1 year after implantation.
\end{abstract}

Key words: implant, antenna, antenna collar, radio transmitter, avian, sea duck, harlequin duck, Histrionicus histrionicus

\section{Introduction}

Radio transmitters that are externally attached to waterfowl can alter survival or return rates, ${ }^{1-4}$ behavior, ${ }^{5-8}$ and reproduction rates. ${ }^{1,2,6,8-10}$ External transmitters attached with sutures suffer unacceptable rates of loss. ${ }^{1,11}$ Transmitters that use internal coiled antennas ${ }^{12-16}$ implanted in the coelom of mallards (Anas platyrhynchos) do not affect reproduction. ${ }^{1}$ However, transmitters that are completely implanted suffer transmission path loss, which reduces signal strength and limits detection range.

From the US Geological Survey, Alaska Science Center, 1011 East Tudor Rd, Anchorage, AK 99503-6119, USA (Mulcahy, Esler); and Alaska Veterinary Pathology Services, PO Box 773072, Eagle River, AK 99577, USA (Burek).

Present address (Esler): Centre for Wildlife Ecology, Simon Fraser University, 5421 Robertson Road, RR1, Delta, British Columbia V4K 3N2, Canada.
Radio transmitters that use a percutaneous antenna that maximizes signal output can now be implanted into the avian coelom. ${ }^{17,18}$ The technique was used to implant satellite transmitters into spectacled eiders (Somateria fischeri), permitting monitoring of the movements of implanted birds migrating to molting and overwintering areas in the Bering Sea. ${ }^{19,20}$ The technique was also used to study seabirds. ${ }^{21}$ In more than 300 harlequin ducks (Histrionicus histrionicus) that were implanted with radio transmitters, the mortality rate was low during surgery (1.5\%) and the 14-day postrelease period $(1.5 \%)$, when most complications are expected to occur. ${ }^{22}$ Implanted transmitters did not affect annual survival rates of harlequin ducks because recapture rates of implanted birds were identical to those of banded but not implanted birds. ${ }^{23}$ Implanted transmitters were found to be an unbiased method for estimating survival of harlequin ducks. ${ }^{24}$ 
Theoretically, the risks of coelomitis and airsacculitis from pathogens migrating along the antenna passage through the body wall are controlled by the use of a fabric-covered tube that forms a collar at the base of the antenna. Histopathologic reactions of captive mallards to the implant and the antenna collar occur as soon as 28 days after implantation. ${ }^{18}$ The purpose of this study was to determine if fabric collars of percutaneous antennas prevent infection in free-ranging birds that were implanted with radio transmitters. For this purpose, we examined histologic, hematologic, and biochemical results in harlequin ducks that were implanted with radio transmitters with percutaneous antennas and fabric collars 12 months earlier.

\section{Materials and Methods}

Radio transmitters with percutaneous antennas were implanted into 100 adult female harlequin ducks captured in Prince William Sound, Alaska, in 1995, as part of an oil spill recovery project that examined overwinter survival of this species. All surgeries were done onboard a chartered vessel. The transmitters (Advanced Telemetry Systems, Isanti, MN, USA) were roughly spherical in shape (1.7-2.4 cm diameter), weighed $15 \mathrm{~g}$, and were embedded in resin. A $20-\mathrm{cm}$ wire antenna was attached to the transmitter. A custom antenna collar (CBD-1, Vascath Corporation, Mississauga, Ontario, Canada) was fitted to the base of the antenna of each transmitter and sealed with silicone adhesive. The collar consisted of a 0.5 -cm-wide strip of $100 \%$ polyester plush fabric glued with silicone adhesive around the surface of a plastic tube with a 2-mm internal diameter. The surgical technique used for implantation was previously described. ${ }^{22}$ Numbered aluminum US Fish and Wildlife Service leg bands were applied to all implanted birds, and the birds were returned to their capture sites approximately 1 hour after surgery.

In 1996, 17 of the birds implanted in 1995 were recaptured and identified by their leg-band numbers. Because of the ongoing oil spill recovery study and a reluctance to further reduce a population already affected by the oil spill, birds were not euthanatized to remove the previously implanted transmitters. Transmitters were surgically removed, and intact antenna collars were recovered from 13 ducks. The birds were anesthetized and prepared for surgery in a manner identical to that used for the original implantation. ${ }^{22}$ After making a midline incision, viscera were retracted to the left side of the coelom to reveal the transmitter. Each transmitter was covered with a fibrous capsule, the ventral and rostral aspects of which contained adhesions to internal organs. Adhesions were partially broken down by blunt dissection, and the fibrous covering of the transmitter was incised with a scalpel blade along approximately half the length of the transmitter body. The transmitter was gently extracted from its covering, and moderate traction was applied to the transmitter body to release the antenna collar from its attachment to the internal body wall. In some cases, pieces of the fibrous covering remained attached to the antenna collar when it was removed through the incision. The body wall around the antenna at its exit site was not dissected because of the potential for causing significant morbidity. Applying traction to the collar released the silicon adhesive holding it to the antenna base and freeing the collar from the antenna. The separated collars and the associated fibrous tissue were placed in $10 \%$ buffered formalin, and the remaining fibrous covering was left in the coelom. A 2-layer, simple continuous suture closure (3-0 Vicryl, Ethicon Inc, Somerville, NJ, USA) was used to repair the incision, and the antenna exit site was closed in a single layer with a simple interrupted suture.

In 1995, blood samples were collected from 6 birds at the time that the radio transmitters were implanted and again in 1996, when the antenna collars were recovered and submitted for histopathologic examination. In each case, a 6-ml blood sample was collected from the jugular vein. Whole blood smears were made on glass microscope slides. A 2-ml aliquot of blood was placed in a glass tube that contained ethylenediaminetetraacetic acid, and the remainder of the blood was allowed to clot in a glass tube at ambient temperature. The clotted blood was centrifuged, and the serum was separated and frozen at $-20^{\circ} \mathrm{C}$. Whole-blood and frozen serum samples, packed in insulated boxes with frozen gel packs, were picked up from the boat by a float plane and flown to Cordova, Alaska, where the samples were placed on a commercial jet for shipment to a commercial laboratory (Avian and Exotic Animal Clinical Pathology Laboratories, Redondo Beach, CA, USA) for hematologic and serum biochemical analysis. Electrolyte, alkaline phosphatase, and gamma glutamyltransferase levels were not measured 
in 1995. Results of hematologic testing and serum biochemical analysis were compared with reference values (D. M. M., unpublished data, October 1997) established for this species.

Ten antenna collars with adherent tissue were submitted for histopathologic examination and were sectioned transversely. After examining these initial samples, an additional 3 collars with no visible adherent tissue were sectioned longitudinally to determine if bacteria had penetrated the length of the collar and had been introduced into the coelom. Because of the lack of adherent tissue, further analysis and scoring were not done on collars sectioned longitudinally. Sections were stained with hematoxylin and eosin, trichrome stain, and tissue Gram's stain. Transverse sections were scored for the presence and the amount of collagen; the degree of granulocyte, plasma-cell, and giant-cell infiltration; and the thickness of the inflammatory membrane. Sections were scored subjectively as mild, moderate, or severe inflammation based on the degree of inflammation, the amount of degenerated debris, and the level of fibrosis observed. To objectively score the number of granulocytes (heterophils and eosinophils), plasma cells, and multinucleated giant cells present, cells in 10 fields were counted at $\times 40$ magnification, and mean and standard deviation were calculated. Because inflammation predominately occurred along the interface between the plastic tube and the attached fabric, fields were chosen at that site. The degree of fibrosis was scored according to a numerical scale: 1) very light background of fine collagen fibers, 2) presence of some dense collagen fibers, and 3) markedly thickened tissue and separation of antenna collar fibers by the presence of thick collagen fibers. A mean fibrosis score was then calculated.

Hematologic and biochemical data were tested for normal distribution by using the Kolmogorov-Smirnov test. For normally distributed data, means of data from 1995 and 1996 were compared with reference values by 2 -tailed paired $t$ test. For non-normally distributed data, medians were compared by using the Mann-Whitney rank sum test.

The mean counts of granulocytes, plasma cells, and multinucleated giant cells from collars with bacteria were compared with those from collars without bacteria by a 2-tailed $t$ test. Differences were considered statistically significant at $P<.05$. Statistical analyses were done by using SigmaStat 3.01 (SPSS, Chicago, IL, USA).

\section{Results}

The US Fish and Wildlife Service leg bands applied to birds implanted with transmitters in 1995 were necessary to identify birds captured in 1996 because antennas on many birds had broken off at the skin level..$^{25}$ Each transmitter had been in place for approximately 12 months and could be palpated as a firm, fixed mass in the right caudal quadrant of the coelom.

Thirteen transmitters implanted in 1995 were removed in 1996. The exit sites of the percutaneous antennas were well healed, with no visible surrounding induration, redness, or exudate. Incision sites were also well healed, and scars were either minimal or not visible. In all birds, the body of the intracoelomic transmitter was covered with a pink-to-red sheath of fibrous connective tissue that was $1-2 \mathrm{~mm}$ thick. Transmitters were fixed in place by adhesions to viscera and the body wall, the fibrous covering, and the antenna collar at the antenna exit site. Extensive adhesions at the site of the previous surgical incision complicated surgical removal of the transmitters, and transmitters had to be removed by incising their fibrous coverings. No abscesses or cysts were detected in the coelomic cavity. Occasionally, a small amount of caseous white material was found between the transmitter and the fibrous covering.

Ten collars were examined histologically in cross section and 3 in longitudinal section. Collars from broken or unbroken antennas were not distinguished. In cross section, the inflammatory reaction was most pronounced within the fabric adjacent to the plastic tube, where larger numbers of granulocytes, lymphocytes, and plasma cells were found relative to the more peripheral fabric (Fig 1). A mild $(n=1)$, moderate $(n=6)$, or severe $(n=3)$ inflammatory reaction was characterized by formation of a fibrous capsule infiltrated with granulocytes, lymphocytes, plasma cells, and multinucleated giant cells. Giant cells surrounding the fibers were consistent with a foreign-body reaction (Fig 2). A rim of degranulated granulocytes was visible adjacent to the plastic tubing in all collars. Bacterial colonies, consisting primarily of gram-positive cocci, were present in 8 of 10 collars examined in cross section (Fig 3). Samples with bacteria evident in the sections had higher mean counts of granulocytes and plasma cells, and lower mean counts of multinucleated giant cells than did samples without bacteria, but these differences were not significant (Table 1). In the 3 collars examined longitudinally, bacterial contamination extended the full length of the collar. 


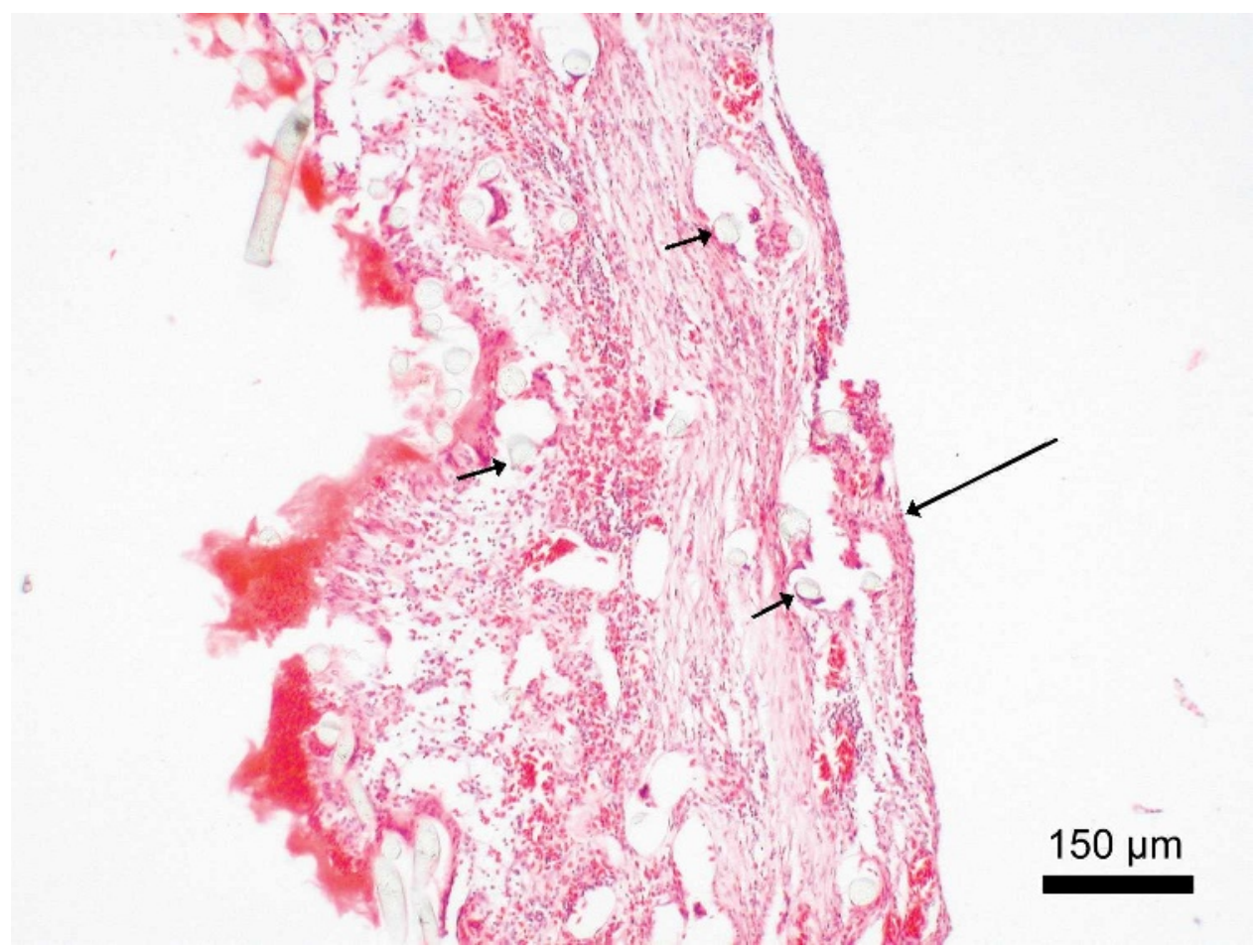

Figure 1. Cross section of an antenna collar removed 12 months after a radio transmitter was implanted in a harlequin duck. The external surface (long arrow) contains primarily collagen and small numbers of mixed inflammatory cells. The interface with the plastic catheter tubing on the inner surface (left) contains a dense mat of degranulated granulocytes and bacterial colonies. The velour fibers (short arrows) are yellow, refractile, and distributed throughout the section. Hematoxylin and eosin. Bar $=150 \mu \mathrm{m}$.

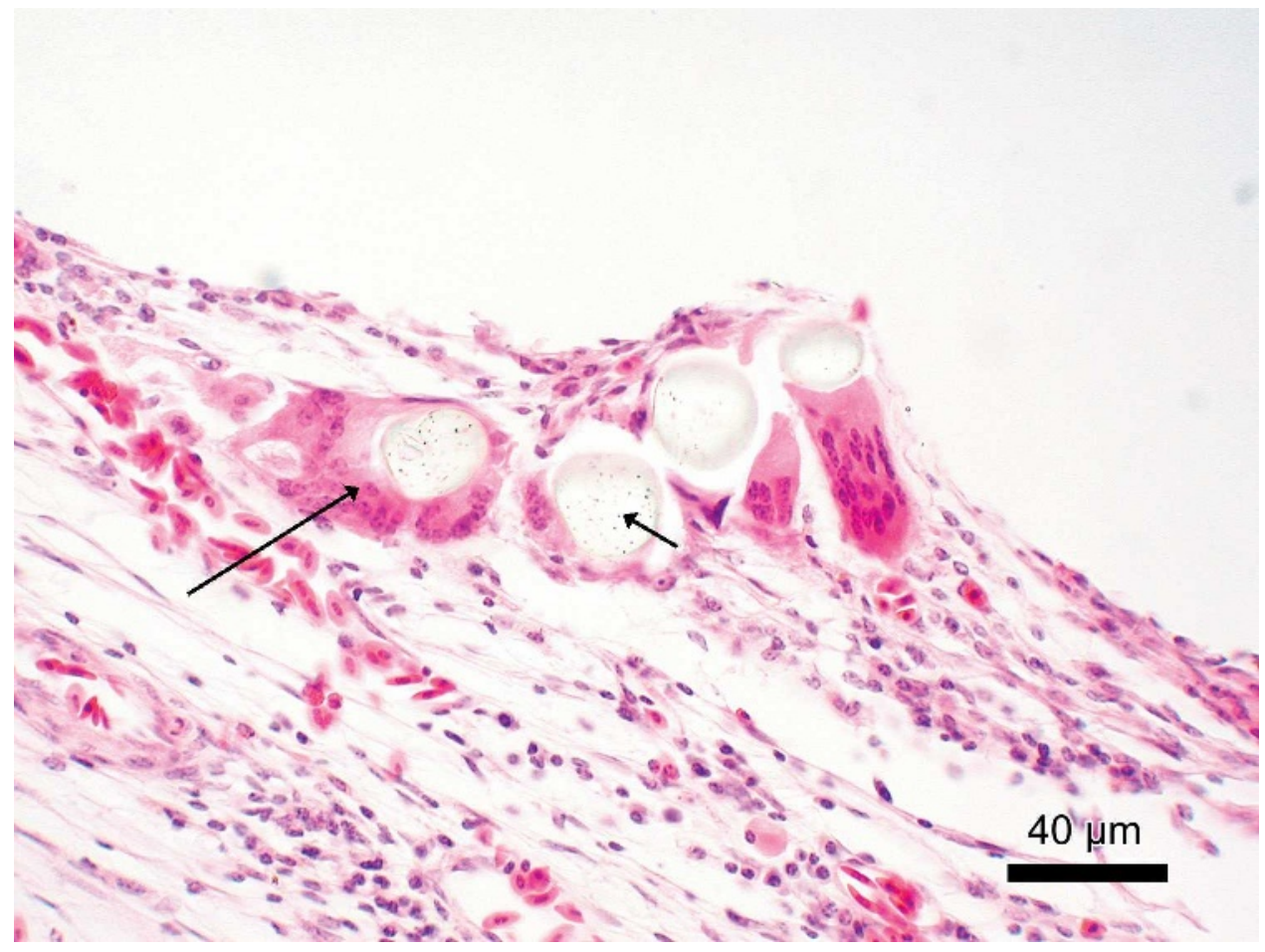

Figure 2. Cross section of an antenna collar removed from a harlequin duck, as described in Figure 1. The velour fibers are yellow and refractile (short arrow). Most fibers are surrounded by a rim of multinucleated giant cells (long arrow). Hematoxylin and eosin. Bar $=40 \mu \mathrm{m}$. 


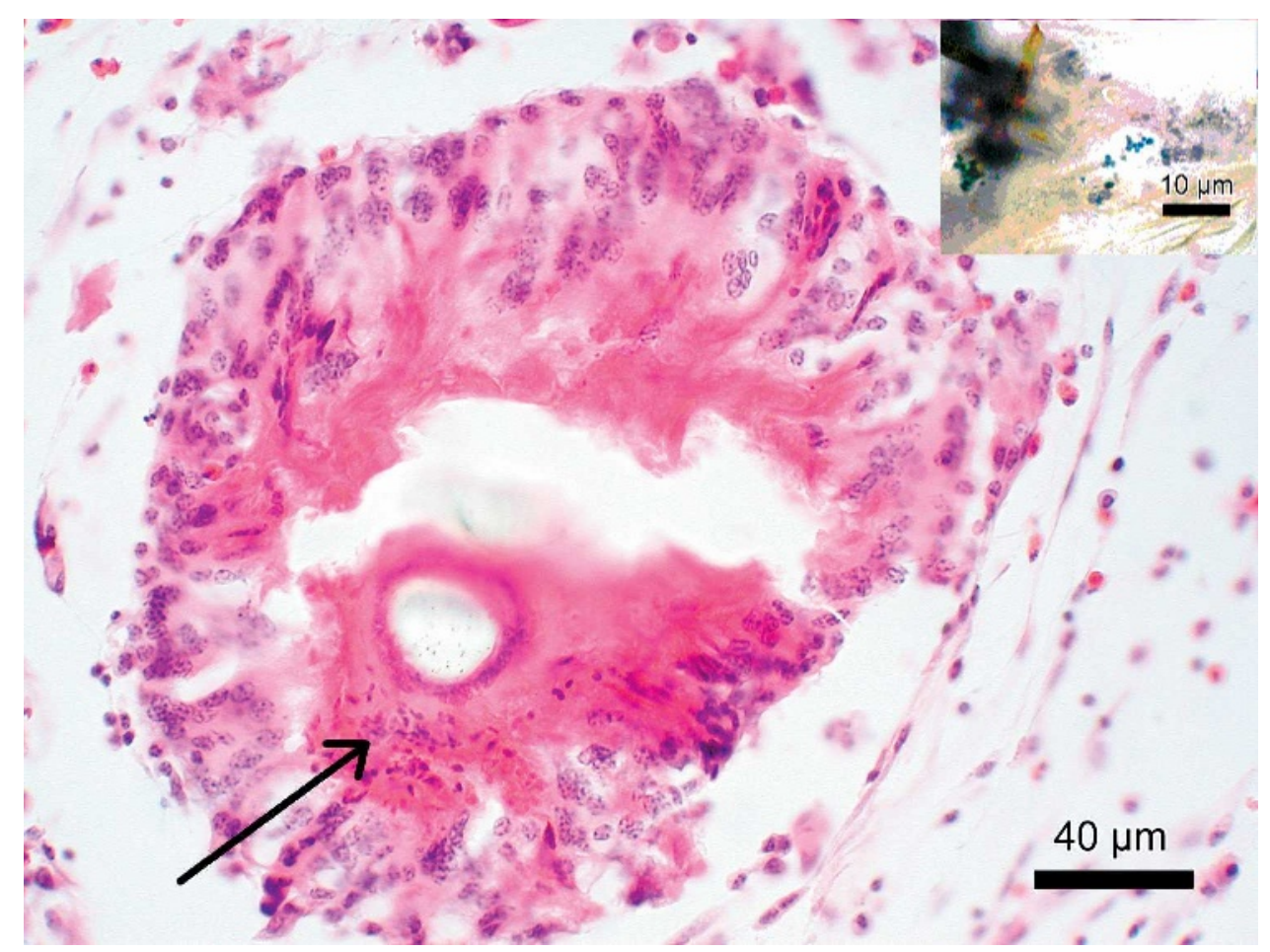

Figure 3. Cross section of an antenna collar removed from a harlequin duck, as described in Figure 1. A rim of degranulated granulocytes (arrow) surrounded some of the velour fibers in all collars. Hematoxylin and eosin. Bar $=$ $40 \mu \mathrm{m}$. Inset: Bacteria surrounding the fibers and present within degranulated granulocytes along the inner rim of the antenna collar in 8 of 10 collars examined. Bacteria are predominantly gram-positive cocci. Gram's stain. Bar = $10 \mu \mathrm{m}$.

Hematologic and biochemical values of 6 ducks implanted and phlebotomized in 1995 were compared with values obtained when they were recaptured and phlebotomized in 1996, when the antenna collars were removed. In these birds, only lactate dehydrogenase, aspartate aminotransferase (AST), and uric acid concentrations differed significantly between the 2 years (Table 2). Mean ( \pm standard deviation) lactate dehydrogenase concentration was significantly lower in 1995 $(347 \pm 119 \mathrm{IU} / \mathrm{L})$ than in $1996(483 \pm 166 \mathrm{IU} / \mathrm{L})$ $(P=.008)$, as were concentrations of AST (1995: $56 \pm 11 \mathrm{IU} / \mathrm{L} ; 1996: 83 \pm 16 \mathrm{IU} / \mathrm{L} ; P=.004)$ and uric acid (1995: $6.4 \pm 3.9 \mathrm{mg} / \mathrm{dl} ; 1996: 11.7 \pm$
$2.4 \mathrm{mg} / \mathrm{dl} ; P=.004)$. Compared with reference values, the mean sodium level $(205 \mathrm{mEq} / \mathrm{L})$ was slightly high in 1996, as was the median percentage of monocytes in 1995, but differences were not significant. Mean concentrations of potassium and glucose were relatively low in both years. All other mean or median values from both years were within reference ranges.

\section{Discussion}

In this study, we found that fabric collars attached to percutaneous antennas were not a barrier to bacterial infection in harlequin ducks

Table 1. Number of inflammatory cells and fibrosis scores of 10 harlequin ducks from samples of velour fabric antenna collars sectioned transversely with and without bacteria present.

\begin{tabular}{|c|c|c|c|c|c|}
\hline \multirow[b]{2}{*}{ Collar samples } & \multirow[b]{2}{*}{ No. } & \multicolumn{3}{|c|}{$\begin{array}{l}\text { Cell counts } \\
\text { mean }( \pm \mathrm{SD})\end{array}$} & \multirow{2}{*}{$\begin{array}{c}\text { Fibrosis score }^{\mathrm{b}} \\
\text { mean }( \pm \mathrm{SD})\end{array}$} \\
\hline & & Granulocytes & Plasma cells & Multinuclear giant cells & \\
\hline Bacteria present & 8 & $66(51)$ & $19(13)$ & $8(6)$ & $2(0.7)$ \\
\hline Bacteria absent & 2 & $20(18)$ & $13(10)$ & $16(1)$ & $1(0)$ \\
\hline
\end{tabular}

${ }^{a}$ Cell counts are cells per high dry field $(\times 40)$.

${ }^{\mathrm{b}}$ Fibrosis is scored by a numerical scale: 1) very light background of fine collagen fibers, 2) presence of some dense collagen fibers, and 3) markedly thickened tissue and separation of antenna collar fibers by thick collagen fibers. 
Table 2. Hematologic and serum biochemical results from 6 female harlequin ducks implanted with transmitters and phlebotomized in 1995 and recaptured and phlebotomized in 1996 when the transmitters were removed. ${ }^{a}$

\begin{tabular}{|c|c|c|c|}
\hline & 1995 & 1996 & Reference interval $^{\mathrm{b}}$ \\
\hline White blood cell count, $\times 10^{3}$ cells $/ \mu 1$ & $15.0(4.7)$ & $11.9(1.7)$ & $6.6-30.0$ \\
\hline Red blood cell count, $\times 10^{6}$ cells $/ \mu 1$ & $3.0(0.6)$ & $3.4(0.6)^{\mathrm{c}}$ & $2.15-4.74$ \\
\hline Packed cell volume, \% & $55(3)$ & $51(4)$ & $44-64$ \\
\hline Mean corpuscular volume, fl & $181(27)$ & $148(30)^{\mathrm{c}}$ & $105-223$ \\
\hline Hemoglobin, g/dl & $15.1(1.5)$ & $12.6(4.1)^{\mathrm{c}}$ & $8.6-20.1$ \\
\hline $\begin{array}{l}\text { Mean corpuscular hemoglobin } \\
\text { concentration, g/dl }\end{array}$ & $27.0(3.7)$ & $24.0(6.6)^{\mathrm{c}}$ & $17.0-38.0$ \\
\hline Heterophils, \% & $75(9)$ & $76(7)$ & $54-90$ \\
\hline Lymphocytes, \% & $21(7)$ & $21(10)$ & $10-45$ \\
\hline Monocytes, \% & $0(0-7)$ & $0(-)$ & 0 \\
\hline Eosinophils, \% & $0.5(0-7)$ & $0(0-7)$ & $0-7$ \\
\hline Basophils, \% & $3(2)$ & $1.5(1.5)$ & $0-5$ \\
\hline Sodium, $\mathrm{mEq} / \mathrm{L}$ & $-\mathrm{d}$ & $205(103)^{\mathrm{e}}$ & $138-202$ \\
\hline Potassium, mEq/L & $\mathrm{d}^{\mathrm{d}}$ & $3.5(2.3)$ & $2.0-5.0$ \\
\hline Gamma glutamyltransferase, IU/L & $\perp^{\mathrm{d}}$ & $12.0(3.9)$ & $0-18$ \\
\hline Alkaline phosphatase, IU/L & $\square^{\mathrm{d}}$ & $473(370)$ & $88-1020$ \\
\hline Calcium, mg/dl & $10.7(0.7)$ & $11.7(1.5)$ & $8.5-14.2$ \\
\hline Creatine phosphokinase, U/L & $1419(985)$ & $963(620)^{\mathrm{e}}$ & $366-4252$ \\
\hline Glucose, $\mathrm{mg} / \mathrm{dl}$ & $392(328-421)$ & $388(356-420)$ & $267-486$ \\
\hline Lactic dehydrogenase, IU/L & $347(119)^{\mathrm{f}}$ & $483(166)^{\mathrm{f}}$ & $146-902$ \\
\hline Phosphorus, mg/dl & $\ldots \mathrm{d}$ & $4.1(0.9)$ & $2.0-8.4$ \\
\hline Aspartate aminotransferase, IU/L & $56(11)^{\mathrm{f}}$ & $83(16)^{f}$ & $16-163$ \\
\hline Total protein, g/dl & $3.5(0.6)$ & $4.3(0.8)$ & $2.6-5.4$ \\
\hline Uric acid, mg/dl & $6.4(3.9)^{\mathrm{f}}$ & $11.7(2.4)^{\mathrm{f}}$ & $4.0-16.8$ \\
\hline
\end{tabular}

${ }^{\text {a }}$ Data are expressed as means (SD), except for monocytes, eosinophils, and glucose, which are non-normally distributed and given as median (range).

${ }^{\mathrm{b}}$ Reference intervals are from harlequin ducks captured on the unoiled side of Prince William Sound (D. M. M., unpublished data, October 1997).

${ }^{\mathrm{c}} \mathrm{n}=3$.

${ }^{\mathrm{a}}$ Not done.

${ }^{\mathrm{e}} \mathrm{n}=5$

${ }^{\mathrm{f}}$ Significant at $P<.05$.

that were implanted intracoelomically with radio transmitters. However, because birds were able to effectively wall off infection inside a fibrotic covering of the transmitter, the mortality rate 12 months after implantation was not affected.

Bacterial infection and active inflammatory reaction were evident in 11 of the 13 antenna collars examined, despite the normal appearance and excellent survival rate of the implanted birds. One year after implantation of radio transmitters, virtually no visible skin reactions were apparent in 13 ducks at the exit sites of the antenna through the body wall. Nonetheless, bacteria penetrated the full length of the antenna collar, posing the possibility of coelomic infection and airsacculitis. The most significant active inflammation and bacterial colonization occurred at the interface of the plastic tube and the collar fabric. However, the overall score for inflammation could not be predicted by the presence or the absence of bacteria in the collars.
The fabric antenna collars applied to the base of percutaneous wire antennas attached to birds are an offshoot of technology developed for artificial organ implants, ${ }^{26}$ extended peritoneal dialysis in human patients, ${ }^{27}$ and arterial grafts. ${ }^{28}$ In theory, connective tissue grows into the collar and epithelium grows down to the collar-collagen junction, which stabilizes the implant and acts as a barrier to bacterial invasion of the coelomic cavity. Radio transmitters have been implanted in several species of seabirds and sea ducks that were released onto water immediately after anesthetic recovery, ${ }_{19,20,29}$ with excellent survival. ${ }^{22}$ Therefore, the collars were also intended to prevent leakage of seawater into the air sacs and coelomic cavity.

Any percutaneous implant introduces the possibility for infection because of the direct path from the implanted foreign structure to the external environment. The transmitter initially was physically attached by a single absorbable suture placed percutaneously through the body 
wall and into the collar. Extrusion of implanted radios occurred in harlequin ducks ${ }^{25}$ a result of the physiologic mechanisms of wound healing actively attempting to expel foreign materials and seal integumentary lesions. ${ }^{30}$

In the implanted ducks, the transmitters and the antenna collars were surrounded intracoelomically by granulation tissue and a fibrous capsule, and collagen fibers were deeply embedded in the synthetic fibers of the collar. Movement of implants was limited by adhesions of the fibrotic capsule to internal organs. In humans with implants, collars are presumed not to be a barrier to infection but rather to act to stabilize the implant, thus preventing the pistonlike movement of percutaneous components that would tend to spread infection deeper into tissues. ${ }^{31}$ Percutaneous devices that clinically appear free of complications often have evidence of inflammation and infection when examined histologically. ${ }^{30}$ The mammalian tissue response to implanted foreign material, such as prosthetic breast implants, involves a chronologic progression: formation of fibrous scar tissue, histiocytic inflammatory response, giant-cell reaction, synovial-like metaplasia, and calcification. ${ }^{32}$ The foreign-body reaction begins within a few hours after surgery and likely persists for the life of the implant..$^{21,33}$ Factors that may increase the risk of infection along the tract to the percutaneous device are blood-clot formation during surgery, trauma to or movement of the implant, and lack of postsurgical care. Most of these factors cannot be controlled in a field study situation.

In mallards that were implanted with radio transmitters attached to percutaneous antennas with fabric collars, the skin at the antenna exit site was essentially normal 1 week later, with the exception of the presence of a small amount of dried exudate. ${ }^{18}$ By 28 days after transmitter placement, adhesions were present around the transmitters and antenna collars. These adhesions consisted of connective tissue lined by multinucleated giant cells, consistent with a foreign-body reaction. Similarly, in rats implanted subcutaneously with polyester material, a moderate-tosevere granulomatous reaction with giant cells formed and persisted for at least 30 days before subsiding, leaving the synthetic fibers surrounded by fibrous sheaths. ${ }^{34}$ In captive mourning doves (Zenaida macroura), transmitters with percutaneous antennas not equipped with fabric collars were implanted subcutaneously or intracoelomically; these relied on a snug fit between the skin and the antenna to form a seal. ${ }^{35}$ This technique was successful in this nonaquatic bird, although there was concern about infection because of increased peripheral heterophil:lymphocyte ratios observed in birds with intracoelomic transmitters. When the doves were euthanatized 10 weeks after implantation, the few complications observed included dehiscence of the surgical incision, transmitter migration (subcutaneously implanted devices), infection of the antenna tract, leakage of transmitter battery fluid, and transmitter failure.

The low serum potassium and glucose concentrations observed in some birds in this study were attributed to a lack of feeding and weather stress. Concentrations of creatine phosphokinase and AST were not increased, as would be expected if the capture technique and holding environment were excessively stressful. ${ }^{36}$ Total white blood cell counts did not differ significantly between 1995 and 1996. In rats, peripheral leukocyte counts increase the day after surgical implantation; however, a sustained systemic response is unlikely once the implant has been encapsulated, which occurs in as little as 3 weeks in rats and 4 weeks in ducks. ${ }^{18,37}$ Overall, none of the hematologic or biochemical data suggests that carrying the transmitter in the coelom for a year causes chronic systemic stress in harlequin ducks.

In this study, the implanted ducks were returned to their natural environment 1 hour after recovery from surgery. Presumably, the antenna collar protected the coelomic cavity from contamination, initially by blood clots that formed on the collar fabric and later by fibrous connective tissue that formed from cells migrating into the fabric. The effectiveness of the fibrous connective tissue covering of the transmitter in preventing contamination of the air sacs and coelom was evidenced by the survival of harlequin ducks that removed their implanted transmitters in the coelom by pulling them through the antenna exit site. ${ }^{25}$ The use of the transmitters in these ducks did not increase 1year mortality rates. ${ }^{24}$ This fibrous seal is especially important in diving birds in which the pressure on the antenna passage site increases during a dive. We conclude that bacterial penetration along the length of the fabric collar of percutaneous antennas attached to radio transmitters implanted coelomically is not a critical factor in morbidity or mortality 1 year after implantation in harlequin ducks. Implanted ducks effectively walled off the transmitter with a fibrotic capsule, which limited the spread of bacterial contamination. 
Acknowledgments: This study was part of a larger study supported by the Exxon Valdez Oil Spill Trustee Council. Conclusions are the authors' and do not necessarily reflect the views or positions of the Trustee Council. Mention of trade names does not constitute government endorsement of products.

\section{References}

1. Rotella JJ, Howerter DW, Sankowski TP, Devries JH. Nesting effort by wild mallards with three types of radio transmitters. J Wildl Manag. 1993; 57:690-695.

2. Ward DH, Flint PL. Effects of harness-attached transmitters on premigration and reproduction of brant. J Wildl Manag. 1995;59:39-46.

3. Dzus EH, Clark RG. Effects of harness-style and abdominally implanted transmitters on survival and return rates of mallards. J Field Ornithol. 1996; 67:549-557.

4. Schmutz JA, Morse JA. Effects of neck collars and radio transmitters on survival and reproduction of emperor geese. J Wildl Manag. 2000;64:231-237.

5. Greenwood RJ, Sargeant AB. Influence of radio packs on captive mallards and blue-winged teal. $J$ Wildl Manag. 1973;37:3-9.

6. Gilmer DS, Ball IJ, Cowardin LM, Reichman JH. Effects of radio packages on wild ducks. $J$ Wildl Manag. 1974;38:243-252.

7. Perry MC. Abnormal behavior of canvasbacks equipped with radio transmitters. $J$ Wildl Manag. 1981;45:786-789.

8. Pietz PJ, Krapu GL, Greenwood RJ, Lokemoen JT. Effects of harness transmitters on behavior and reproduction of wild mallards. $J$ Wildl Manag. 1993;57:696-703.

9. Bergmann PJ, Flake LD, Tucker WL. Influence of brood rearing on female mallard survival and effects of harness-type transmitters. J Field Ornithol. 1994;65:151-159.

10. Paquette GA, Devries JH, Emery RB, et al. Effects of transmitters on reproduction and survival of wild mallards. J Wildl Manag. 1997;61:953-961.

11. Houston RA, Greenwood RJ. Effects of radio transmitters on nesting captive mallards. $J$ Wildl Manag. 1993;57:703-709.

12. Korschgen CE, Maxson SJ, Kuechle VB. Evaluation of implanted radio transmitters in ducks. J Wildl Manag. 1984;48:982-987.

13. Olsen GH, Dein FJ, Haramis GM, Jorde DG. Implanting radio transmitters in wintering canvasbacks. J Wildl Manag. 1992;56:325-328.

14. Haramis GM, Jorde DG, Bunke CM. Survival of hatching-year female canvasbacks wintering in Chesapeake Bay. J Wildl Manag. 1993;57:763-771.

15. Hohman WL, Pritchert RD, Moore JL, Schaeffer DO. Survival of female canvasbacks wintering in coastal Louisiana. J Wildl Manag. 1993;57: $758-762$.
16. Hohman WL, Moore JL, Franson JC. Winter survival of immature canvasbacks in inland Louisiana. J Wildl Manag. 1995;59:384-392.

17. Korschgen CE, Kenow KP, Austin JE, et al. An automated telemetry system for studies of migrating diving ducks. In: Neuman MR, Amlaner CJ Jr, Cristalli C, eds. Biotelemetry XIII. Terre Haute, IN: Indiana State University Press; 1995:179-184.

18. Korschgen CE, Kenow KP, Gendron-Fitzpatrick $A$, et al. Implanting intra-abdominal radiotransmitters with external whip antennas in ducks. J Wildl Manag. 1996;60:132-137.

19. Petersen MR, Douglas DC, Mulcahy DM. Use of implanted satellite transmitters to locate spectacled eiders at-sea. Condor. 1995;97:276-278.

20. Petersen MR, Larned WW, Douglas DC. At-sea distribution of spectacled eiders: a 120-year-old mystery resolved. Auk. 1999;116:1009-1020.

21. Hatch SA, Meyers PM, Mulcahy DM, Douglas DC. Seasonal movements and pelagic habitat use of murres and puffins determined by satellite telemetry. Condor. 2000;102:145-154.

22. Mulcahy DM, Esler D. Surgical and immediate postrelease mortality of harlequin ducks (Histrionicus histrionicus) implanted with abdominal radio transmitters with percutaneous antennae. $J$ Zoo Wildl Med. 1999;30:397-401.

23. Esler D, Schmutz JA, Jarvis RL, Mulcahy DM. Winter survival of adult female harlequin ducks in relation to history of contamination by the Exxon Valdez oil spill. J Wildl Manag. 2000;64: 839-847.

24. Esler D, Mulcahy DM, Jarvis RL. Testing assumptions for unbiased estimation of survival of radiomarked harlequin ducks. $J$ Wildl Manag. 2000;64:591-598.

25. Mulcahy DM, Esler D, Stoskopf MK. Loss from harlequin ducks of abdominally implanted radio transmitters equipped with percutaneous antennas. J Field Ornithol. 1999;70:244-250.

26. Hall CW, Liotta D, O'Neal RM, et al. Medical applications of the velour fabrics. Ann N Y Acad Sci. 1968;146:314-324.

27. Dasse KA, Daly BDT, Bousquet G, et al. A polyurethane percutaneous access device for peritoneal dialysis. In: Khanna R, Nolph KD, Prowant $\mathrm{BF}$, et al, eds. Advances in Continuous Ambulatory Peritoneal Dialysis. Toronto, Canada: University of Toronto Press. Peritoneal Dialysis Bulletin 1988:245-252.

28. Link J, Feyerabend B, Grabener M, et al. Dacroncovered stent-grafts for percutaneous treatment of carotid aneurysms: effectiveness and biocompatibility-experimental study in swine. Radiology. 1996;200:397-401.

29. Meyers PM, Hatch SA, Mulcahy DM. Effect of implanted satellite transmitters on the nesting behavior of murres. Condor. 1998;100:172-174. 
30. Von Recum AF, Park JB. Permanent percutaneous devices. Crit Rev Bioeng. 1981;5:37-77.

31. Twardowski ZJ, Dobbie JW, Moore HL, et al. Morphology of peritoneal dialysis catheter tunnel: macroscopy and light microscopy. Perit Dial Int. 1991;11:237-251.

32. Yeoh G, Russell P, Jenkins E. Spectrum of histological changes reactive to prosthetic breast implants: a clinicopathological study of 84 patients. Pathology. 1996;28:232-235.

33. Maturri L, Azzolini A, Campiglio GL, Tardito E. Are synthetic prostheses really inert? Preliminary results of a study on the biocompatibility of Dacron vascular prostheses and silicone skin expanders. Int Surg. 1991;76:115-118.
34. Lansdown ABG, Sirivongs D, Vuttivirojana A. Experimental evaluation of local reactions due to Dacron used in Tenckhoff catheters for peritoneal dialysis. ASAIO J. 1995;41:202-204.

35. Schulz JH, Burmudez AJ, Tomlinson JL, et al. Effects of implanted radiotransmitters on captive mourning doves. J Wildl Manag. 1998;62: 1451-1460.

36. Dabbert CB, Powell KC. Serum enzymes as indicators of capture myopathy in mallards (Anas platyrhynchos). J Wildl Dis. 1993;29:304-309.

37. Guo W, Willén R, Andersson R, et al. Morphological response of the peritoneum and spleen to intraperitoneal biomaterials. Int $J$ Artif Organs. 1993;16:276-284. 